\title{
Poor outlook for arms control
}

\section{Something needs to be done to break the deadlock at the parallel bilateral negotiations at Geneva. Other governments could help. Even a summit meeting might be worth the risk.}

HOPES that 1983 would bring substantial progress on arms control are fading fast. That is the obvious but depressing inference from what politicians in Moscow and Washington and negotiators in Geneva have been saying in the past few days. The latest disappointment is the swift and hostile response in the Soviet Union to the new negotiating position on strategic weapons announced last week by President Reagan, on the eve of his negotiator's departure for the resumption of the Strategic Arms Reduction Talks (START) at Geneva.

On the face of things, the United States seems to have conceded one important point on which the Soviet Union has for several months been pressing - that aircraft capable of delivering nuclear weapons should be counted in the strategic balance. It has also devised a workable way of making progress towards a more modest balance of strategic forces. The objective that there should be a reduction of the number of strategic warheads deployed of at least five per cent a year may be too modest to satisfy everybody, but anything is better than nothing. Moreover, the notion that these reductions should mostly be achieved by taking out of deployment more warheads installed on existing weapons than would be added on new missiles would have been less interesting to the Soviet Union than to the United States. But the principle of "build-down"' is attractive, if only as a model for the future. It is a shame that it has been dismissed so quickly.

The Geneva negotiations on weapons of intermediate range (called INF) are messier. The Soviet Union has stolidly resisted the notion that its deployment in the past five years of SS20 missiles within range of Europe is in any way provocative of the decision of the North Atlantic Treaty Organization (NATO) in 1979 that counterpoising cruise and Pershing II missiles should be deployed in Europe (from the end of this year). That is perverse. While the SS20s do not fall within the definition of what constitutes a strategic missile for the purposes of the unratified Salt II treaty (they cannot reach the United States), their appearance on the European scene was plainly an event of great strategic importance.

The Soviet refrain throughout the INF talks has, however, been that if there is to be an agreement on the numbers of missiles deployed, the British and French nuclear forces must be counted, which is at once reasonable and unreasonable. On one (Soviet) view, the SS20s are merely a counterpoise for the two nonAmerican nuclear forces in Western Europe; on another (AngloFrench), European nuclear arms are strictly strategic in the sense that this is how the governments which operate them define their purpose. The British force (operationally controlled by NATO) is increasingly intended as an assurance that even if the United States commitment to Western Europe becomes shaky, there will be some kind of a nuclear deterrent left. The French force is what it has always been since the 1950s, a way of keeping unwanted visitors out of France. Especially because the two forces appear to have been counted implicitly as strategic in the Salt II agreement, the Soviet Union must know that the United States could not concede this point even if it were constitutionally able to do so. The moral for all concerned is, however, that the START and INF talks must sooner rather than later be thrown together. The attempt to distinguish between strategic and other kinds of nuclear weapons within the tiny compass of Europe makes less and less sense as time goes on.
With both negotiations at Geneva on such shaky ground, however, may it not be too much to hope that this frail forum will survive the deployment of the cruise and Pershing missiles in Western Europe? Already there have been hints that the Soviet Union may withdraw from the negotiations as a mark of its displeasure, while frustration with the Geneva process has some of the government's advisers in Washington complaining that by being apparently the only source of suggestions as to what kind of treaty might be signed, the United States is "negotiating with itself". The danger now is that one side or the other will allow pride to get the better of its judgement. Mercifully, there are influences working the other way. The side responsible for bringing to a halt the only substantial negotiations on arms control now under way will invite not merely displeasure in the public prints but trouble at the next review conference of the NonProliferation Treaty, now less than two years off, when the other signatories will be rightly looking to the superpowers for promised progress towards "effective measures in the direction of nuclear disarmament". Moreover, the issue is not simply which superpower is the least unpopular in the international community: the weapons on which their power rests are too dangerous for that.

What in the circumstances should be done? With all that has happened and not happened in the past few months, and with the emerging need for some kind of formula that would allow the two superpower governments to set off in a new direction without loss of face, nothing less than a personal meeting of the two political leaders (Messrs Andropov and Reagan) will now suffice. Such a meeting could agree that the two sets of talks at Geneva could be profitably combined, implicitly blaming the failures of the past two years on the agenda. It would also be possible to reaffirm the understanding of the two sides at the outset of the Geneva talks, now honoured only in the breach, that negotiations would be conducted in private, not by means of television broadcasts. A summit meeting, however hackneyed the formula, would also allow the two sides to end their public slanging-match about the destruction of the South Korean civil aircraft over Sakhalin. (The leak by the US intelligence services to the New York Times last Friday agreeing that the Soviet military thought they were shooting down a hostile military reconnaissance plane does not excuse the Soviet Union from the charge of incompetence but does mean that a great deal of the rhetoric in the past few weeks has been misplaced.) But may not summit meetings make things worse? (The Kennedy-Khruschev meeting in Vienna in 1962 was after all followed within a year by the Cuban missile crisis.) One measure of the parlous state of affairs now reached is that the risk may be worth taking.

Other governments than those of the superpowers have a part to play. While the Geneva missile talks are too important to be dropped, there is an urgent need to blow away the dust from other almost forgotten negotiations - the comprehensive test-ban treaty aborted in 1980, a sensible treaty on chemical weapons (where again the Soviet Union has disappointed by failing to respond to proposals put up in the Geneva Committee on Disarmament) and even the notion that something might be done to make central Europe a less dangerous place. The best hope is that next year's meeting of the European Security Conference will provide a forum for agreement on some practical steps. 